\title{
Clinical Manifestation of Acute Myocardial Infarction in the Elderly
}

\author{
Miftah Suryadipradja ${ }^{*}$, Wahyu Dewabrata ${ }^{*}$, S. Harun ${ }^{*}$ Idrus Alwi", Lukman Hakim*, Shufrie Effendy*, \\ Dasnan Isamail ${ }^{f}$
}

\begin{abstract}
Abstrak
Telah dilakukan penelitian retrospektif terhadap pasien infark miokard akut (IMA) yang dirawat di ICCU RSUPN Dr Cipto Mangunkusumo, Jakarta antara Januari 1994 sampai Desember 1999. Dari 513 pasien yang dirawat dengan IMA, 227 pasien adalah usia lanjut, di mana 35,2 \% dari mereka adalah wanita. Sebagian besar IMA usia lanjut mengeluh nyeri dada yang khas seperti pada pada kelompok usia muda. Pasien IMA usia lanjut cenderung terlambat datang ke rumah sakit dan lebih banyak menderita IMA gelombang $Q$. Faktor risiko diabetes melitus dan hipertensi lebih sering dijumpai pada usia lanjut. Prevalensi fibrilasi atrial dan mortalitas lebih tinggi pada usia lanjut. (Med J Indones 2003; 12: 229-35)
\end{abstract}

\begin{abstract}
A retrospective study were performed in patients with acute myocardial infarction (AMI) that hospitalized in ICCU Cipto Mangunkusumo hospital, Jakarta during the period of January 1994 until Decmber 1999. There were 513 patients hospitalized with MCI, 227 patients (44.2\%) were classified as elderly, and 35.2\% of them were female. Most of the elderly AMI patients reported typical chest pain just like their younger counterparts. Elderly AMI patients tend to come later to the hospital, and more $Q$-wave myocardial infarction were identified compared to non-Q-wave myocardial infarction. Risk factors of diabetes mellitus and hypertension were more common among the elderly. The prevalence of atrial fibrillation and the mortality rate were higher among elderly AMI patients. (Med J Indones 2003; 12: 229-35)
\end{abstract}

Keywords : clinical manifestation, acute myocardial infarction, elderly

Coronary heart disease is the most common disease found in the elderly and makes up two thirds of all causes of cardiac death. Approximately $60 \%$ of patients hospitalized with acute myocardial infarction (AMI) are over 65 years old. ${ }^{1}$ Clinical manifestations of acute myocardial infarction in the elderly differ from that in younger patients. Typical chest pain is rarely found among the elderly, and complaints are usually atypical. ${ }^{1-8}$ There is an increase in the morbidity and mortality of AMI in the elderly. Approximately $80 \%$ of all deaths due to AMI occur in patients over 65 years of age. ${ }^{9}$ Non-Q wave myocardial infarction is more commonly found among elderly patients with AMI and

\footnotetext{
* Division of Cardiology, Department of Internal Medicine, Faculty of Medicine University of Indonesia, Dr. Cipto Mangunkusumo Hospital, Jakarta, Indonesia

${ }^{f}$ Department of Internal Medicine, Faculty of Medicine University of Indonesia, Dr. Cipto Mangunkusumo Hospital, Jakarta, Indonesia
}

is more common among women. ${ }^{1,5,6,7}$ Elderly patients with AMI demonstrate a minimal increase in creatine kinase $(\mathrm{CK})$ enzyme. ${ }^{10}$ Atypical complaints, atypical electrocardiogram (ECG) and minimal increase in creatine kinase makes establishing the diagnosis of AMI among the elderly difficult.

The aim of the study is to determine clinical manifestation, prognosis, and the complications of acute myocardial infarction among the elderly hospitalized in the Intensive Cardiac Care Unit (ICCU) of Dr. Cipto Mangunkusumo Public Central Referral General Hospital and compare them to those of younger patients.

\section{METHODS}

This retrospective study was performed on AMI patients hospitalized in the ICCU of Dr. Cipto Mangunkusumo General Hospital from January 1994 to December 1999. A diagnosis of AMI is established 
if two out of three of the AMI criteria are found: 1) typical chest pain, 2) typical electrocardiogram, 3) an increase of creatine-kinase (CK-CKMB) enzyme of at least twice the highest normal level. ${ }^{11}$ Elderly AMI patients refer to patients aged 60 years or above. Some characteristics of the patients were recorded, consisting of subjective complaints, risk factors, infark type, hospital arrival time, proportion of patients receiving thrombolytic agent and complications of AMI.

All of the above characteristics in elderly patients were compared with those in patients younger than 60 years. Statistical analysis used were Chi-square and Fisher's exact test.

\section{RESULTS}

Five hundreds and thirteen patients have been hospitalized for AMI during the periode of January 1994 to December 1999. Two hundred and twenty seven $(44,2 \%)$ were classified as eldrely and $35,2 \%$ of them were female.

\section{Distribution of complaints}

In general, chest pain was still the most common complaint, found in $83.3 \%$ among patients with AMI (see Table 1), and typical AMI is still in a higher rank than atypical complaints. Epigastric pain is found in $4.9 \%$ of patients, while dizziness and headache accompanied by myocardial infarction is found in $1.9 \%$ and $1 \%$ of cases. Another complaint was found in 1 patient $(0.2 \%)$.

Table 1. Distribution of complaints in 412 AMI patients

\begin{tabular}{lcc}
\hline \multicolumn{1}{c}{ Complaint } & Present & Not present \\
\hline Chest pain & $343(83.3 \%)$ & $69(16.7 \%)$ \\
Cold sweat & $173(42.0 \%)$ & $239(58.0 \%)$ \\
Nausea & $87(21.1 \%)$ & $325(78.9 \%)$ \\
Difficulty breathing & $64(15.5 \%)$ & $348(84.5 \%)$ \\
Heaviness on the chest & $51(12.4 \%)$ & $361(87.6 \%)$ \\
Palpitations & $49(11.9 \%)$ & $363(88.9 \%)$ \\
Weakness & $49(11.9 \%)$ & $363(88.9 \%)$ \\
Sharp pain & $42(10.2 \%)$ & $370(89.8 \%)$ \\
Vomiting & $32(7.8 \%)$ & $380(92.2 \%)$ \\
Heartburn & $26(6.3 \%)$ & $386(93.7 \%)$ \\
Fatigue & $9(2.2 \%)$ & $403(97.8 \%)$ \\
Dizziness & $8(1.9 \%)$ & $404(98.1 \%)$ \\
Hepresentche & $4(1.0 \%)$ & $408(99.0 \%)$ \\
Fainting & $3(0.7 \%)$ & $409(99.3 \%)$ \\
Other & $1(0.2 \%)$ & $411(99.8 \%)$ \\
\hline
\end{tabular}

Table 2 shows the distribution of complaints classified according to age group. Aside from nausea and heartburn, which were more prevalent among the elderly AMI patients, no complaints showed a significant difference in prevalence among the elderly AMI patients and the younger ones.

\section{Characteristics of AMI patients according to age group}

There were more female elderly patients than younger ones with AMI, as shown in Table 3. The length of time spent before entering the hospital was significantly longer for elderly AMI patients compared to younger ones. There were more elderly non-Q wave AMI patients than younger ones. There was significantly lower increase in the level of creatinase kinase (CK) among elderly AMI patients than younger ones, while the difference in the increase in the level for CKMB between the two age groups was not significant. Treatment with thrombolytic was significantly less often used among elderly AMI patients compared to younger ones.

\section{Risk factors according to age group}

More elderly AMI patients presented no risk factors than younger ones. There was significantly more elderly AMI patients who were non-smokers and had no family history of AMI. Diabetes mellitus and hypertension was significantly more prevalent among elderly AMI patients compared to younger ones. (Table 4)

\section{Complications of AMI according to age group}

Complications of AMI in elderly as well as younger patients are shown in table 5. Atrial fibrilation was significantly more common among elderly AMI patients compared to younger ones, while other complications were not significantly different. Death was significantly more frequent among elderly AMI patients compared to younger ones. 
Table 2. Distribution of complaints according to age group

\begin{tabular}{|c|c|c|c|c|c|}
\hline & \multicolumn{4}{|c|}{ Age group } & \multirow{3}{*}{$\boldsymbol{P}$} \\
\hline & \multirow{2}{*}{$\frac{<60}{\text { Present }}$} & \multicolumn{3}{|c|}{$>60$} & \\
\hline & & Not present & Present & Not present & \\
\hline Chest pain & $\begin{array}{c}185 \\
(84.9 \%) \\
\end{array}$ & $\begin{array}{c}33 \\
(15.1 \%) \\
\end{array}$ & $\begin{array}{c}157 \\
(81.3 \%) \\
\end{array}$ & $\begin{array}{c}36 \\
(18.7 \%) \\
\end{array}$ & 0.341 \\
\hline Cold sweat & $\begin{array}{c}92 \\
(42.2 \%) \\
\end{array}$ & $\begin{array}{c}126 \\
(57.8 \%) \\
\end{array}$ & $\begin{array}{c}81 \\
(42.0 \%) \\
\end{array}$ & $\begin{array}{c}112 \\
(58.0 \%) \\
\end{array}$ & 0.962 \\
\hline Nausea & $\begin{array}{c}38 \\
(13.8 \%) \\
\end{array}$ & $\begin{array}{c}180 \\
(86.2 \%) \\
\end{array}$ & $\begin{array}{c}49 \\
(19.2 \%)\end{array}$ & $\begin{array}{c}144 \\
(80.8 \%) \\
\end{array}$ & 0.049 \\
\hline Difficulty breathing & $\begin{array}{c}33 \\
(12.8 \%) \\
\end{array}$ & $\begin{array}{c}185 \\
(87.2 \%) \\
\end{array}$ & $\begin{array}{c}31 \\
(15.2 \%) \\
\end{array}$ & $\begin{array}{c}162 \\
(84.8 \%) \\
\end{array}$ & 0.796 \\
\hline Pressure & $\begin{array}{c}25 \\
(11.7 \%) \\
\end{array}$ & $\begin{array}{c}193 \\
(88.3 \%) \\
\end{array}$ & $\begin{array}{c}26 \\
(14.4 \%)\end{array}$ & $\begin{array}{c}167 \\
(85.6 \%) \\
\end{array}$ & 0.539 \\
\hline Palpitations & $\begin{array}{c}26 \\
(11.7 \%)\end{array}$ & $\begin{array}{c}192 \\
(88.3 \%)\end{array}$ & $\begin{array}{c}23 \\
(11.2 \%)\end{array}$ & $\begin{array}{c}170 \\
(88.8 \%)\end{array}$ & 0.998 \\
\hline Weakness & $\begin{array}{c}31 \\
(11.7 \%) \\
\end{array}$ & $\begin{array}{c}187 \\
(88.3 \%) \\
\end{array}$ & $\begin{array}{c}18 \\
(10.4 \%) \\
\end{array}$ & $\begin{array}{c}175 \\
(89.6 \%) \\
\end{array}$ & 0.127 \\
\hline Sharp pain & $\begin{array}{c}25 \\
(13.8 \%) \\
\end{array}$ & $\begin{array}{c}193 \\
(86.2 \%) \\
\end{array}$ & $\begin{array}{c}17 \\
(9.6 \%) \\
\end{array}$ & $\begin{array}{c}176 \\
(90.4 \%) \\
\end{array}$ & 0.374 \\
\hline $\begin{array}{l}\text { Pain extending to the } \\
\text { back }\end{array}$ & $\begin{array}{c}15 \\
(6.4 \%)\end{array}$ & $\begin{array}{c}200 \\
(93.6 \%)\end{array}$ & $\begin{array}{c}19 \\
(13.6 \%)\end{array}$ & $\begin{array}{c}174 \\
(86.4 \%)\end{array}$ & $0.069^{*}$ \\
\hline Vomiting & $\begin{array}{c}18 \\
(5.3 \%) \\
\end{array}$ & $\begin{array}{c}200 \\
(94.7 \%) \\
\end{array}$ & $\begin{array}{c}14 \\
(5.6 \%) \\
\end{array}$ & $\begin{array}{c}179 \\
(94.4 \%) \\
\end{array}$ & $0.322 *$ \\
\hline $\begin{array}{l}\text { Pain extending to the } \\
\text { arm }\end{array}$ & $\begin{array}{c}13 \\
(7.4 \%) \\
\end{array}$ & $\begin{array}{c}205 \\
(92.6 \%) \\
\end{array}$ & $\begin{array}{c}14 \\
(7.2 \%)\end{array}$ & $\begin{array}{c}179 \\
(92.8 \%) \\
\end{array}$ & $0.818^{*}$ \\
\hline Heartburn & $\begin{array}{c}14 \\
(2.1 \%) \\
\end{array}$ & $\begin{array}{c}204 \\
(97.9 \%) \\
\end{array}$ & $\begin{array}{c}12 \\
(8.8 \%) \\
\end{array}$ & $\begin{array}{c}181 \\
(91.2 \%) \\
\end{array}$ & $0.021 *$ \\
\hline Epigastric pain & $\begin{array}{c}9 \\
(4.3 \%) \\
\end{array}$ & $\begin{array}{c}209 \\
(95.7 \%) \\
\end{array}$ & $\begin{array}{c}11 \\
(7.2 \%) \\
\end{array}$ & $\begin{array}{c}182 \\
(92.8 \%) \\
\end{array}$ & $0.595^{*}$ \\
\hline Fatigue & $\begin{array}{c}5 \\
(3.2 \%) \\
\end{array}$ & $\begin{array}{c}213 \\
(96.8 \%) \\
\end{array}$ & $\begin{array}{c}4 \\
(3.2 \%) \\
\end{array}$ & $\begin{array}{c}189 \\
(96.8 \%) \\
\end{array}$ & $0.464 *$ \\
\hline Dizziness & $\begin{array}{c}3 \\
(1.1 \%) \\
\end{array}$ & $\begin{array}{c}215 \\
(98.9 \%) \\
\end{array}$ & $\begin{array}{c}5 \\
(3.2 \%) \\
\end{array}$ & $\begin{array}{c}188 \\
(96.8 \%) \\
\end{array}$ & $0.776^{*}$ \\
\hline Headache & 0 & $\begin{array}{c}138 \\
(100 \%)\end{array}$ & $\begin{array}{c}4 \\
(1.6 \%)\end{array}$ & $\begin{array}{c}189 \\
(98.4 \%)\end{array}$ & $0.109 *$ \\
\hline Fainting & $\begin{array}{c}3 \\
(2.4 \%) \\
\end{array}$ & $\begin{array}{c}225 \\
(100 \%) \\
\end{array}$ & $\mathbf{0}$ & $\begin{array}{c}193 \\
(100 \%) \\
\end{array}$ & $0.137 *$ \\
\hline Other & $\begin{array}{c}1 \\
(0.8 \%) \\
\end{array}$ & $\begin{array}{c}217 \\
(100 \%) \\
\end{array}$ & $\mathbf{0}$ & $\begin{array}{c}193 \\
(100 \%) \\
\end{array}$ & $0.696^{*}$ \\
\hline
\end{tabular}


Table 3. Characteristics of AMI patients according to age group

\begin{tabular}{|c|c|c|c|c|}
\hline & & \multicolumn{2}{|c|}{ Age group } & \multirow{2}{*}{$\mathrm{P}$} \\
\hline & & $<60$ & $\geq 60$ & \\
\hline \multirow[t]{3}{*}{ Sex } & Female & $36(12.59 \%)$ & $80(35.24 \%)$ & \multirow{3}{*}{0.000} \\
\hline & Male & $250(87.41 \%)$ & $147(64.76 \%)$ & \\
\hline & Total & $286(100.0 \%)$ & $227(100.0 \%)$ & \\
\hline \multirow[t]{4}{*}{ Hospital arrival time } & $\leq 6$ hours & $133(50.76 \%)$ & $76(37.25 \%)$ & \multirow{4}{*}{0.013} \\
\hline & $6-12$ hours & $42(16.03 \%)$ & $38(18.63 \%)$ & \\
\hline & $>12$ hours & $87(33.21 \%)$ & $90(44.12 \%)$ & \\
\hline & Total & $262(100.0 \%)$ & $204(100.0 \%)$ & \\
\hline \multirow[t]{3}{*}{ Infarct type } & Non-Q & $67(23.43 \%)$ & $71(31.28 \%)$ & \multirow{3}{*}{0.046} \\
\hline & Q & $219(76.57 \%)$ & $156(68.72 \%)$ & \\
\hline & Total & $286(100.0 \%)$ & $227(100.0 \%)$ & \\
\hline \multirow[t]{3}{*}{ CK } & $<380$ & $125(47.71 \%)$ & $118(57.56 \%)$ & \multirow{3}{*}{0.034} \\
\hline & $>380$ & $137(52.29 \%)$ & $87(42.44 \%)$ & \\
\hline & Total & $262(100.0 \%)$ & $205(100.0 \%)$ & \\
\hline \multirow[t]{3}{*}{ CKMB } & $<50$ & $160(67.1 \%)$ & $133(65.84 \%)$ & \multirow{3}{*}{0.632} \\
\hline & $>50$ & $102(38.93 \%)$ & $69(34.16 \%)$ & \\
\hline & Total & $262(100.0 \%)$ & $202(100.0 \%)$ & \\
\hline \multirow[t]{3}{*}{ Thrombolytic agents } & Administered & $59(20.63 \%)$ & $19(8.37 \%)$ & \multirow{3}{*}{0.000} \\
\hline & Not administered & $227(79.37 \%)$ & $208(91.63 \%)$ & \\
\hline & Total & $286(100.0 \%)$ & $227(100.0 \%)$ & \\
\hline
\end{tabular}

Table 4. Risk factors of AMI patients according to age group

\begin{tabular}{|c|c|c|c|c|}
\hline & & \multicolumn{2}{|c|}{ Age group } & \multirow{2}{*}{$\mathrm{P}$} \\
\hline & & $<60$ & $\geq 60$ & \\
\hline \multirow[t]{3}{*}{ Risk factor } & Present & $270(94.41 \%)$ & $201(88.55 \%)$ & \multirow{3}{*}{0.016} \\
\hline & Not present & $16(5.59 \%)$ & $26(11.45 \%)$ & \\
\hline & Total & $286(100.0 \%)$ & $227(100.0 \%)$ & \\
\hline \multirow[t]{4}{*}{ Family history } & Present & $30(10.49 \%)$ & $12(5.29 \%)$ & \multirow{4}{*}{0.036} \\
\hline & Not present & $250(87.41 \%)$ & $211(92.95 \%)$ & \\
\hline & ND? & $6(2.10 \%)$ & $4(1.76 \%)$ & \\
\hline & Total & $286(100.0 \%)$ & $227(100.0 \%)$ & \\
\hline \multirow[t]{3}{*}{ Smoking } & Present & $191(66.78 \%)$ & $93(40.97 \%)$ & \multirow{3}{*}{0.000} \\
\hline & Not present & $95(33.22 \%)$ & $134(59.03 \%)$ & \\
\hline & Total & $286(100.0 \%)$ & $227(100.0 \%)$ & \\
\hline \multirow[t]{3}{*}{$\mathrm{DM}$} & Present & $53(18.53 \%)$ & $66(29.07 \%)$ & \multirow{3}{*}{0.005} \\
\hline & Not present & $233(81.47 \%)$ & $161(70.93 \%)$ & \\
\hline & Total & $286(100.0 \%)$ & $227(100.0 \%)$ & \\
\hline \multirow[t]{3}{*}{ Hypertension } & Present & $132(46.2 \%)$ & $125(55.10 \%)$ & \multirow{3}{*}{0.045} \\
\hline & Not present & $154(53.8 \%)$ & $102(44.09 \%)$ & \\
\hline & Total & $286(100.0 \%)$ & $227(100.0 \%)$ & \\
\hline \multirow[t]{3}{*}{ Dyslipidemia } & Present & $70(24.48 \%)$ & $45(19.82 \%)$ & \multirow{3}{*}{0.210} \\
\hline & Not present & $216(75.52 \%)$ & $182(80.18 \%)$ & \\
\hline & Total & $286(100.0 \%)$ & $227(100.0 \%)$ & \\
\hline
\end{tabular}


Table 5. Complications of AMI patients according to age group

\begin{tabular}{|c|c|c|c|c|}
\hline & & \multicolumn{2}{|c|}{ Age group } & \\
\hline & & $<60$ & $\geq 60$ & \\
\hline \multirow[t]{3}{*}{ Heart failure } & Present & $68(24.11 \%)$ & $63(28.25 \%)$ & \multirow{3}{*}{0.292} \\
\hline & Not present & $214(75.89 \%)$ & $160(71.75 \%)$ & \\
\hline & Total & $282(100.0 \%)$ & $223(100.0 \%)$ & \\
\hline \multirow[t]{3}{*}{$\mathrm{AF}$} & Present & $14(4.90 \%)$ & $42(18.50 \%)$ & \multirow{3}{*}{0.000} \\
\hline & Not present & $272(95.10 \%)$ & $185(81.50 \%)$ & \\
\hline & Total & $286(100.0 \%)$ & $227(100.0 \%)$ & \\
\hline \multirow[t]{3}{*}{ VES } & Present & $89(31.12 \%)$ & $82(36.12 \%)$ & \multirow{3}{*}{0.232} \\
\hline & Not present & $197(68.88 \%)$ & $145(63.88 \%)$ & \\
\hline & Total & $286(100.0 \%)$ & $227(100.0 \%)$ & \\
\hline \multirow[t]{3}{*}{ VT } & Present & $25(8.74 \%)$ & $23(10.13 \%)$ & \multirow{3}{*}{0.591} \\
\hline & Not present & $261(91.26 \%)$ & $204(89.87 \%)$ & \\
\hline & Total & $286(100.0 \%)$ & $227(100.0 \%)$ & \\
\hline \multirow[t]{3}{*}{ VF } & Present & $19(6.64 \%)$ & $24(10.57 \%)$ & \multirow{3}{*}{0.111} \\
\hline & Not present & $267(93.36 \%)$ & $203(89.43 \%)$ & \\
\hline & Total & $286(100.0 \%)$ & $227(100.0 \%)$ & \\
\hline \multirow[t]{3}{*}{ RBBB } & Present & $19(6.64 \%)$ & $18(7.93 \%)$ & \multirow{3}{*}{0.576} \\
\hline & Not present & $267(93.36 \%)$ & $209(92.07 \%)$ & \\
\hline & Total & $286(100.0 \%)$ & $227(100.0 \%)$ & \\
\hline \multirow[t]{3}{*}{ LBBB } & Present & $4(1.40 \%)$ & $5(2.20 \%)$ & \multirow{3}{*}{$0.518^{*}$} \\
\hline & Not present & $282(98.60 \%)$ & $222(97.80 \%)$ & \\
\hline & Total & $286(100.0 \%)$ & $227(100.0 \%)$ & \\
\hline \multirow[t]{3}{*}{ Death } & Dead & $37(12.94 \%)$ & $72(31.72 \%)$ & \multirow{3}{*}{0.000} \\
\hline & Alive & $249(87.06 \%)$ & $155(68.28 \%)$ & \\
\hline & Total & $286(100.0 \%)$ & $227(100.0 \%)$ & \\
\hline
\end{tabular}

\section{DISCUSSION}

According to literature, elderly AMI patients rarely present typical chest pain. AMI patients present chest pain in $80 \%$ of cases among those 65 years or less, $72 \%$ among 66-74 years olds, and $49 \%$ in those 75 years or more. Patients often present atypical complaints such as fatigue, weakness, syncope, confusion, cold sweats, difficulty in breathing, vertigo, vomiting, epigastric pain, or even often present to complaints at all. ${ }^{1-8}$ In the elderly, acute myocardiac infarct present difficulty breathing in $22 \%$ of cases, chest pain in $21 \%$, syncope in $8 \%$, stroke in $7 \%$, confusion and giddiness in $20 \%$, sudden death in $8 \%$, and other symptoms in $14 \% .^{7}$ These findings differ from data obtained from the ICCU of Cipto Mangunkusumo Hospital, where most of the elderly patients still presented typical chest pain and statistically did not significantly differ in presenting symptom compared to their younger counterparts. Nevertheles, the elderly were more commonly found with gastrointestinal symptoms, particularly nausea $(p<0.05)$. Thus, we have to be alert when an elderly patient comes with dyspepsia. The prevalence of chest pain did not significantly differ among age groups. There were significantly a larger proportion of females among elderly AMI patients than among younger AMI patients, which has also been noted by Paul. $^{5}$

Arrival time to the hospital was shorter in young patients than in older ones. It seems that elderly myocardiac infarction patients take a longer time to arrive at the hospital or seek medical attention, which 
affects the choice of treatment at the hospital, since they have often passed the golden period. We can see from the data above that fewer elderly patients receive thrombolytic agents. This is also associated with arrival at the hospital past the golden period. The Second International Study of Infarct Survival (ISIS2) reported that thrombolytic agents can reduce the mortality risk in the elderly. The mortality rate of elderly patients receiving streptokinase and aspirin is $15.8 \%$, compared to $23.8 \%$ of those receiving placebo. ${ }^{12}$

Paul SM et al found that there were more elderly myocardial infarction patients with non-Q wave MI. Non Q-wave MI is found in $76 \%$ of AMI patients over 75 years of age, $67 \%$ of those ages $66-74$ years, and $56 \%$ in those 65 years or less. ${ }^{5}$ However, data from the ICCU of Cipto Mangunkusumo General Hospital demonstrated a higher prevalence of Q-wave MI than non Q-wave MI, even though the proportion of non-Q wave MI was still significantly higher among elderly AMI patients than among their younger counterparts. Non-Q wave MI is more common in the elderly due to increased collaterals in order to protect the heart from transmural infarction.

There is a lower increase of CK enzyme in elderly AMI patients compared to younger patients, it is thought to be associated with reduced lean body mass in the elderly. ${ }^{10}$

Risk factors of diabetes mellitus and hypertension were more common among the elderly, while smoking, dyslipidemia and family history of AMI were more common among the younger patients. The same findings were reported by Paul. ${ }^{5}$

Atrial fibrillation was significantly more common among elderly AMI patients than among their younger counterparts, while the prevalence of other complications were not significantly different among the two age groups. Other complications are more common among elderly AMI patients. 1 The mortality rate is significantly higher among elderly AMI patients than among younger AMI patients. Paul reported a 5\% mortality rate among AMI patients less than 65 years of age, $8 \%$ among AMI patients ages 66-74 years, and 19\% among patients over 75 years of age $(\mathrm{p}<0.001) .^{5}$

Smith SC reported a hospital mortality rate of $20 \%$ among AMI patients over 75 years of age, and 12\% among those ages $65-75$ years. ${ }^{13}$ Due to atypical complaints, elderly AMI patients often come to the hospital too late, and atypical electrocardiogram causes a lower use of thrombolytic agents, which influences mortality. ${ }^{14,15}$

It is concluded that the elderly constitutes $44,2 \%$ of AMI patients and 35,2\% of them were female. Most of the elderly AMI patients reported typical chest pain just like their younger counterparts. Elderly AMI patients tend to come later to the hospital, and more Q-wave myocardial infarction were identified compared to non-Q-wave myocardial infarction. Risk factors of diabetes mellitus and hypertension were more common among the elderly, while smoking, dyslipidemia, and family history, were more commonly identified among the younger AMI patients. The prevalence of atrial fibrillation and the mortality rate were higher among elderly AMI patients.

\section{REFERENCES}

1. Wenger NK. The eIderly patient with cardiovascular disease. Heart Dis 2000; 2:31-61.

2. Golberg RJ, Gore JM, Gurwitz JH et al. The impact of age on the incidence and prognosis of initial acute myocaraial infarction. The Worcester Heart Attack Study Am Heart J 1989:117:543-9.

3. Nadelmann J, Firshman WH, Ooi W(J. et al. Prevalence, incidence and prognosis of recognized and unrecognized myocardial infarction in per persons age 75 years or older: the Bronx Aging Study.Am J Cardiol1990; 66:533- 7.

4. Solomon CG, Lee TH, Cook EF et al. Comparison of clinical presentation.of acute myocardial infarction in patients older than 65 years of age to younger patients: the Multicenter Chest Pain Study experiene. Am J Cardiol 1989; 63: 772-6.

5. Paul SD, O'Gaza PT, Mahjoub ZA et al. Geriatric patients with acute myocardial infarction: cardiac risk factor profiles, presentation, thrombolysis coronary interventions and prognosis, Am Heart J 1996; 131: 710-5.

6. Wei JY. Coronary heart disease In: Hazzard WR. Blass JP, Ettinger WH et al, Editors. Principles of Geriatric Medicine and Gerontology 4th ed. New york; McGrawHiI1:1999.p. 661- 8.

7. Crepaldi G, Scognamigli R. Myocardial infarction in Evans JG, Williams TF, Bcattie BL, editors. Oxford Text book of Geriatric Medicine. 2 nd. Oxford: Oxford university Press; 2000.p. 394-402.

8. Gurwitz JH, MC L.aughlin T J, Willison DJ et al. Delayed hospital presentation in patien whO have had acute myocardial infarction. Ann Intern Med 1997; 126: 593- 9.

9. Marcus, Friday K, Mc Cans J, et al. Age related prognosis after acute myocardial infarction: the multicenter Diltiazem Postinfarction trial. Am J Cardiol 1990; 65:559-66.

10. Hong RA, Licht JD, Wei JY et al. Elevated CK-MB with normal total creatine kinase in suspected myocardial infarction: Asociated clinical findings and early prognosis Am Heart J 1986;111: 1041-7. 
11. The Joint European Society of Cardiology/American College of Cardiology Committe. Myocardial infarction redefined. A consensus document of The Joint European Society of Cardiology/American College of Cardiology Committee for the Redefinition of Myocardial Infarction. Eur Heart J 2000; 21: 1502-13.

12. Gruppo Italiano per 10 Studio della Streptocinase neil Infarcto Micardico (GISSI). Effectiveness of intravenous thrombolytic treatment in acute myocardial infarction Lancet 1986; 277:397-401.
13. Smith SC, Gilpin E, Ahnve S. Outlook after acute myocardial infarction in the very elderly compared with that in patients aged 65 to 75 years. J Am Coll Cardiol 1990; 16: 784-92.

14. Delvin W, Cragg Do Jack M, et al. Comparison of outcome in patients with acute myocardial infarction aged $>75$ years with that in younger patients. Am J Cardiol 1995; 75: 573- 6 .

15. Krumholz HM, Murillo JE, Chen J, et al. Thrombolytic therapy for eligible elderly patients with acute myocardial infarction. JAMA 1997;277: 1683-8. 